\title{
The Strategy of Planting Arrangement in College Campus Culture Construction
}

\author{
Wenjun Wang ${ }^{1, a^{*}}$ and Hongxing $\mathrm{Yi}^{1, \mathrm{~b}}$ \\ ${ }^{1}$ City College of WUST, Wuhan, China 430083 \\ a15827425957@163.com, blucyyhxc@126.com
}

Keywords: Campus culture; Campus landscape; Planting arrangement; Culture construction

\begin{abstract}
College campus is the environment of teaching, cultivating taste, building bodies and individual character. Campus as the carrier of Campus culture, with all the teachers, students and staffs in the long-term educational practice, the accumulation of material achievements and spiritual achievements of heritage and creation. Create a beautiful campus environment in colleges and universities is an important way to promote and development of campus culture construction. The planting arrangement in the campus is different from the other types environment. It is more emphasis on culture and heritage. So the planting arrangement is an important part of campus culture construction.
\end{abstract}

\section{Introduction}

College campus is the environment of teaching, cultivating taste, building bodies and individual character. Campus as the carrier of Campus culture, with all the teachers, students and staffs in the long-term educational practice, the accumulation of material achievements and spiritual achievements of heritage and creation. Create a beautiful campus environment in colleges and universities is an important way to promote and development of campus culture construction. The planting arrangement is an important part of campus environment. Innovative, unique, and beautiful campus landscape, free, lively and quiet campus atmosphere, not only to the vast number of teachers, students and staffs in such aspects as thought, morality, discipline, and accomplishment in good effect and influence, but also can create inspiration, cheerful disposition, to inspire the teachers and students positive, enterprising and innovative employees in a good mental state.

The cultural connotation of plant landscape has the importance influence to teachers and students in the campus. Therefore, the cultural connotation of planting arrangement in the campus, not only a simple infrastructure work that concerned about working, study and living environment, but also concerned about the cultural and sprit construction, development and heritage.

\section{Current Situation and Problems}

Campus construction pay more attention to the harmony of human and nature and campus history culture. By the artistic and humanized environment can create a distinctive ecological campus. But pay less consideration to the cultural connotation of planting. Campus is an environment of silent classroom that can influence all the members in the campus. Campus environment can be a good complement with classroom education and shaping students' characters.

Plants is an important part of campus environment. Plants plays a crucial role in the construction of campus environment. It's not only ornamental object but also carrier of campus culture. Every tree and bush in the campus contains rich moral education. With sophisticated, practical and harmony planting arrangement, he human resources, scientific, cultural, knowledge can spread every corner of the campus. So as to improve and enhance the atmosphere of campus culture, the potential connotation of plant should be discovered and developed well.

\section{The Method of Planting Arrangement}

Campus culture is both abstract and concrete. It is embodied in every building's design style, in the manners of all the members in the campus, also in the tree and bush that witness the growth of 
campus. Each plant has its profound connotation of culture. Different ethnic and regions of the people, because of life, culture and history tradition, has certain thoughts and feelings, even conceptual symbol. These were formed after hundreds of years cultural accumulation. It is a very precious cultural treasure.

The campus of colleges and universities is a learning, communication, entertainment, sports, and living place. The main service object is in the period of young college students. The students that lively open, being active, high culture. Therefore, what they need is not only beautiful physical environment, but also need the spirit of high quality environment.

Campus is the home of the teachers, students and staffs, and they are the main activities in the campus, Combination of modern and traditional create a quiet, beautiful, comfortable, cultural, humanistic communication environment for the teachers, students and staffs.

The Influence of Plant. Get the spirit of humanity must pass through the knowledge of humanities education and become the main body consciousness, thoughts, emotions and life experience. The process of shaping students' healthy personality is learning knowledge skills, emotional experience and practice. Using cultural connotation of plant characteristics in the campus will have important positive significance.

The cultural connotation of plant is a creative expression of human emotional and spiritual life. And lots of cultural plant landscape contains specific information, emotions and ideas.

The cultural planting landscape in the campus, guides the student comprehending the classic works of art, emotion and thoughts. And enrich the students' spiritual world, purify the mind, edify sentiment, cultivate a positive, optimistic attitude and so on has a prominent role. Plants are various and colorful, giving person with visual esthetics, attractive fragrance from flowers and so on. It also can create a kind of auditory beauty, making people full of enjoyment. Trees and flowers breeds life, it showed different beauties. The reasonable arrangement of plants can produce certain artistic conception, such as phoenix tree leaf falls, the world known autumn, telling students cherish the time; the combination of flowering peach and cherry plum means have students everywhere. On the selection of plant species always follows the rules as: flowers blossoming in spring, shading everywhere in summer, colorful view in autumn, plum with snow in winter, telling the spirit fruitful achievements of the campus. Campus environment is an ecological beauty, artistic beauty and scientific beauty environment. Such an environment can incentive cohesive force, produce the sense of belonging and responsibility to the teachers and students. It also inspire students to strive forward, study diligently.

The Cultural Connotation of Plant. Material campus culture is the surface part of campus. It is the foundation of spirit and material culture. These cultural facilities in the form of the material object, can meet the cultural needs of teachers and students at the same time, but also can show the unique spirit culture with the cultural connotation plants in the campus. And the teachers and students in it were subtle influenced in a long term.

Culture. Culture can be transmitted from the historical and cultural connotation, unconsciously make people take a certain culture. First, choose a kind of plant that can reflect campus culture as a school tree or school flower. The plant's character match with school history, educational philosophy, educational goals and determine. It can be plant that is graceful, ornamental or cultural features match with the spirit of the campus and become one of the unique view in the campus. Each campus has natural history and cultural history, through the special trees to recognize and interpret history is another way. Ancient tree is a symbol of history, is the accumulation of culture, and make people feel the culture and had a profound artistic conception. Plant in the campus shows the historic context, reflects the social civilization, shape the unique features, encourage students to the know the history, set positive ambitions and outlook on life. Secondly, put the pictures on the wall and corridor with different plant's characteristics and unique cultural connotation. It can help people know ancient or famous people giving different plants with unique cultural connotation. With exquisite picture show in the form of a corridor in the campus, the students have the chance to learn something that can't learn from book. Beautiful plants can infect, influence students' personality. It can inheritance of campus culture quietly. 
Popular Science. Establish the botanical garden, science garden, arboretum or horticultural garden, popularize knowledge of plant science. Establish botany, outdoor dendrology and science labs, is to cultivate students to love nature, science, to explore the mysteries of nature, and is of great significance to cultivate students the spirit of scientific research. Diversified social needs high-quality comprehensive talents, in the fierce competition society, teachers and students have a larger study pressure. Teachers and students in such an environment need a place that can release the pressure. If there has a garden where flowers blooming like a piece of brocade, the air was filled with a faint fragrance of flowers, people can discharge pressure.

Ecology. Plant configuration requires the ecology theory as the instruction, to recreate nature, improve and maintain the ecological balance for the purpose. In order to coexist between human and nature as the goal, with the systematic, biological diversity of landscape as the theme of sustainability for the mission. Native plants in configuration is also one of the performance of the ecological campus. Native plant resource and natural plant communities are the result of natural selection for a long time, can adapt to the local ecological environment, do not need special input, it can not only reduce the cost of maintenance management, but also save energy, save water resources, and can reflect local characteristics, creating a characteristic campus plant landscape, also helps to improve the environmental protection consciousness of teachers and students in school.

Interaction. Campus can open up a variety of flower beds, similar to the game scene of happy farm. These small flower beds contracted by the teacher, management by the student who to carry on the simple daily maintenance. It can set up various kinds of plant cultural communities, and kinds of plants, flower art elective courses. At the same time, in the proper season or festivals can organize various activities, such as gardening, flower arrangement, photography, painting and other activities. And these are part of the campus culture construction.

\section{Conclusion}

Colleges as an important base of personnel training place where shaping young student's outlook on life and values. The young students not only learn how to thinking and judging but more important is learning how to living. Campus is not only to create a good physical environment for students, bust also providing a spiritual environment for learning and communication. Campus culture influence on each participant and they ignored the influence. With the continuous development of campus culture, the planting also invested and dissemination of the culture. Each plant in the campus make a contribution to building a characteristic, dynamic, profound cultural background campus.

\section{Acknowledgement}

The research topic of City College of WUST 2016, landscape design- landscaping curriculum construction research and practice. Item number:2016CYYBJY024.

\section{References:}

[1] X.X. Cui: Journal of Chifeng University, Vol. 32 (2016) No.11, p.146.

[2] K. Qiu: Journal of Huaihua University, 2009 No.8, p.127.

[3] Q.J. Yang, L.Q. Chen and C.S. Yang: Hua Zhong Architecture, Vol. 28 (2010) No.10, p.135.

[4] H.J. Zhang: Practice and Exploration on Reconstruction of Plant Landscape in University Campus (MS., Nanjing Agricultural University, China 2012), p.14.

[5] P.F. Ye: Study on Culture Connotation of Plants and Its Application in University Campus-A Case Study of Several Universities in Nanchang (MS., Jiangxi University of Finance and Economics, China 2013), p.24.

[6] M.C. Zhang, P. Lin and P.G. Yun: Journal of Anhui Argi. Sci, Vol. 38 (2010) No.5, p.2702. 
[7] H.J. Tu: Campus Integrated Design -Campus Planning Campus Landscape Campus Architecture (China Architecture \& Building Press, China 2007)

[8] Y.H. Qiu, Y.L. Chen: Journal of HUST, Vol. 24 (2007) No.2, p.75.

[9] J.Z. Yin: Illustrations for Plant Landscape (China Machine Press, China 2011)

[10]Z.Q. Deng: Journal of North China Institute of Science and Technology, Vol. 4 (2007) No.2, p.61. 